\title{
APLIKASI PASSIVE AIR SAMPLER UNTUK PERSISTENT ORGANIC POLLUTANTS DI UDARA AMBIEN
}

\section{PASSIVE AIR SAMPLER FOR DETERMINING PERSISTENT ORGANIC POLLUTANSTS IN AMBIENT AIR}

\author{
Dewi Ratnaningsih ${ }^{1}$
}

(Diterima tanggal 09-06-2015; Disetujui tanggal 15-02-2016)

\begin{abstract}
ABSTRAK
Aplikasi passive air sampler (PAS) untuk pengukuran persistent organic pollutants (POPs) di udara ambien di Indonesia penting dipertimbangkan mengingat masih terbatasnya informasi POPs di udara ambien. Pengambilan sampel POPs dengan pasif ini lebih mudah dan efisien dibandingkan secara aktif. POPs sudah dilarang penggunaannya, namun karena sifatnya yang persisten POPs masih ditemukan di lingkungan. Tujuan penulisan ini untuk menyampaiakan hasil worskhop yang dilakukan di KORDI kerjasama AMETEC-UNU dalam aplikasi PAS untuk pengukuran POPS di udara ambien. PAS yang berisi poliurethan foam (PUF) dipaparkan selama 63 hari di daerah rural Citeko-Puncak dan di urban Cawang Jakarta untuk mengambil sampel gas secara pasif. Hasil pengukuran menunjukkan bahwa beberapa senyawa POPs masih terdeteksi di udara ambien dengan konsentrasi di urban Jakarta lebih tinggi dibandingkan di rural Citeko Bogor. POPs yang terdeteksi di udara ambien adalah $\mathrm{HCB}$, trans-chlordane, cis-chlordane, trans-nonachlor, PCBs, DDT dan turunannya yaitu pp'-DDT, op'-DDT, pp'-DDD, pp'-DDE, dengan kisaran konsentrasi $0.012-0.167 \mathrm{ng} / \mathrm{m}^{3}$. HCB di rural area cenderung berasal dari global transportasi. Total DDT di urban lebih tinggi dibandingkan dengan di rural namun rasio DDT/ DDE $>1$ yang ditemukan di rural area menunjukkan adanya indikasi terjadi masukan baru senyawa DDT. Rasio t rans chlordan/cis chlordane (TT/CC) $>1,2$ di urban juga menunjukkan indikasi terjadinya masukan baru senyawa chlordane. PCB di urban area terdeteksi lebih tinggi dan variasi lebih banyak dibandingkan di rural area, sehingga masih dimungkinkan adanya sumber pencemar lokal. Identifikasi lebih lanjut senyawa POPs yang sudah dilarang penting dilakukan untuk mendukung upaya pengawasan keberadaan senyawa POPs secara ilegal.
\end{abstract}

Kata Kunci : Passive Air Sampling, PUF, POPs, PCBs, HCB, chlordane DDT.

\begin{abstract}
Passive air sampler (PAS) application for measuaring Persistent Organic Pollutants (POPS) in the air is important to be consider due to the limitation of POPs information in the ambient air. Sampling of POPs by using PAS is easier and more efficient than using active sampler. POPs is already banned, however it's still found in the environment caused of persistency. The aim of this report is to deliver workshop result carried by KORDI-AMETECUNU on PAS application for POPs measurement in ambient air. PAS containing polyurethane foam (PUF) were exposed in Citeko-Bogor as rural area and Cawang-Jakarta as urban area for gas sampling passively during 63 days. The results showed that some POPs were detected in ambient air with higher concentration in Jakarta than in Citeko Bogor. Several POP were detected in ambient air in the concentration range of 0012 to $0167 \mathrm{ng}$ / $m 3$ including hexachlorobenzene (HCB), trans-chlordane, cis-chlordane, trans-nonachlor, PCBs, DDT and its derivatives such as $p p^{\prime}-D D T$, op'-DDT, $p p^{\prime}-D D D$, $p p^{\prime}-D D E$. There is possibility of global transportation for $H C B$ pollution in rural area. Total DDT in urban is higher than in rural, but the ratio of DDT / DDE $>1$ were found in rural area showed any indication of new entries of DDT for agricultural applications. Ratio trans chlordan / cischlordane $(T T / C C)>1.2$ in urban also showed indications of new input of chlordane. PCBs were detected higher and more variety in urban area, than in rural area. There is possibility that PCBs pollution still come from local pollution sources. Further identification of banned POP in the envioronment is important to be implemented in order to support controlling illegal presence of POPS..
\end{abstract}

Key word: Passive Air Sampling, PUF, POPs, PCBs, HCB, chlordane,DDT.

\footnotetext{
${ }^{1}$ P3KLL-KLHK. Kawasan PUSPIPTEK Gedung 210, Jln. Raya PUSPIPTEK, Serpong - Tangerang. BANTEN, 15310 - INDONESIA, Telp 021-7560981, email dewirinie@yahoo.com
} 


\section{PENDAHULUAN}

Passive Air Sampler (PAS) dengan Polyurethane Foam (PUF) telah mulai banyak digunakan untuk pemantauan senyawa organik semi volatil di udara ambien secara pasif. Penggunaan PAS banyak memberikan keuntungan dibandingkan dengan peralatan pengambilan sampel secara aktif. Aktif sampler konvensional menggunakan High Volume Air Sampler (HVAS) membutuhkan pompa dan sumber listrik dengan konsekwensi membutuhkan biaya lebih mahal. HVAS ini tidak selalu dapat diaplikasikan terutama bila dibutuhkan pengambilan sampel di banyak titik yang dilakukan secara bersamaan pada lokasi yang berbeda ${ }^{(1)}$. Pengambilan sampel secara pasif selain lebih mahal juga membutuhkan operator yang terlatih. PAS lebih praktis, sederhana, dan tidak membutuhkan tenaga listrik sehingga dapat diaplikasikan di daerah yang tidak ada sumber listrik. PAS juga telah diaplikasikan untuk pemantauan dalam skala yang luas termasuk untuk daerah yang terisolir ataupun daerah yang diasumsikan belum mengalami pencemaran ${ }^{(2,3)}$. PAS dapat digunakan untuk mengatasi gap kekurangan data antara daerah rural dan daerah urban sehingga dapat menilai tingkat perbedaan antara daerah urban dan rural ${ }^{(4)}$. PAS dapat ditempatkan tersebar di banyak titik pantau, sehingga dapat dimanfaatkan untuk pemetaan penyebaran polutan di wilayah yang luas serta pemantauan dalam jangka panjang. Biaya yang rendah dan aplikasi yang mudah ini dapat menjamin bahwa strategi sampling dengan PAS ini dapat memberikan informasi level dari senyawa organik semi volatil dalam kisaran yang diharapkan ${ }^{(5)}$. Penggunaan PAS untuk pemantauan senyawa organik semi volatil dengan waktu paparan yang relatif lama akan lebih mewakili kondisi yang sebenarnya dibandingkan dengan pemantauan aktif secara grab sampel dengan waktu paparan yang singkat

Persistent organic pollutants (POPs) merupakan senyawa toksik yang berdampak negatif terhadap kesehatan manusia dan lingkungan di seluruh dunia(6). POPs juga terdiri dari kelompok senyawa kimia berbahaya yang sangat stabil atau persisten dan bertahan lama di lingkungan, bersifat racun terhadap mahkluk hidup termasuk manusia dan mempunyai efek kronis berupa gangguan pada reproduksi, sistem endokrin, kekebalan dan karsinogenik atau dikatakan juga sebagai senyawa yang termasuk dalam kelompok Endocrine Disrupter Compounds (EDCs). Kelompok senyawa POPs mengalami bioakumulasi dalam tubuh mahkluk hidup melalui jaring jaring makanan dan menimbulkan dampak negatif yang membahayakan bagi manusia dan mahkluk hidup lainnya. Sifat fisika kimia dan persistensi senyawa POPs dapat menyebabkan senyawa tersebut dapat berpindah di lingkungan dan terdistribusi secara global tanpa mengenal batas wilayah dan negara serta dapat terdeteksi pada jarak yang sangat jauh dari sumber pencemar di daerah yang terisolir ${ }^{(3)}$. POPs mempunyai daya larut yang rendah dalam air, namum daya larut yang tinggi dalam lemak, sehingga mudah terakumulasi dengan konsentrasi tinggi di jaringan lemak dan terjadi perbesaran konsentrasi (biokonsentrasi) melalui rantai makanan.

Pada awalnya konvensi Stockholm menetapkan 12 senyawa yang termasuk dalam kelompok POPs yaitu Aldrin, Endrin, Dieldrin, Chlordane, Toxapen, Mirex, Heptachlor, HCB, dan 
$D D T$; bahan kimia industri yaitu $P C B s$; dan produk sampingan yang terbentuk secara tidak sengaja dalam suatu proses yaitu, Furan dan Dioksin. Daftar senyawa POPs semakin bertambah dengan adanya senyawa New POPs seperti BDEs, endosulfan, lindane, PFOs dsb.

Pemantauan POPs pada umumnya telah dilakukan di lingkungan khususnya di media air, tanah maupun sedimen. Walaupun data hasil pemantauan POPs di lingkungan tersebut masih terbatas untuk keseluruhan wilayah Indonesia, namun pemantauan POPs di air, sedimen atau tanah pernah dilakukan. Untuk pemantauan POPs di udara masih jarang dilakukan di Indonesia. Data yang terkait dengan hasil pemantauan POPs di udara masih sangat minim. Terkait dengan hal tersebut maka identifikasi POPs di udara ambien masih diperlukan. Tujuan dari kegiatan ini adalah sebagai aplikasi pemamakaian PAS untuk pengukuran POPs di udara ambien.

\section{METODOLOGI}

\section{Deskripsi sampler}

Pengambilan sampel udara untuk identifikasi senyawa POPs menggunakan Polyurethane foam-disk (PUF-disk) yang dikembangkan oleh Korea Ocean Research and Development Institute (KORDI) berdasarkan tipe Harner. Secara umum PUF-disk yang digunakan mempunyai ukuran: diameter $14 \mathrm{~cm}$, ketebalan $1.35 \mathrm{~cm}$, area permukan $365 \mathrm{~cm}$, volume :207 $\mathrm{cm}^{3}$, ketebalan efektif : $0.567 \mathrm{~cm}$, berat; 4.40 $\mathrm{g}$ dan densitas; $0.0213 \mathrm{~g} / \mathrm{cm}^{3}(7)$.

\section{Preparasi sampler}

PUF-disk yang digunakan untuk pengambilan sampel udara dibersihkan terlebih dahulu demikian juga dengan kaleng stainless stell tempat penyimpanan PUF-disk. Proses preparasi dan pembersihan PUF dilakukan oleh laboratorium Oil and POPs Research Group KORDI, demikian juga dengan kaleng penyimpan PUF-disk. Pembersiahn kaleng penyimpanan PUF-disk yang terbuat dari stainless stell dilakukan dengan dicuci air distilasi, kemudian diultrasonik dan dibilas dengan dichloromethana (DCM). PUF-disk juga dibersihkan dengan dicuci air destilasi secara manual dengan ditepuk tepuk menggunakan tangan bersarung tangan bebas tepung. PUF-disk kemudian dikeringkan semalam pada suhu $60^{\circ} \mathrm{C}$ dan dilakukan ekstraksi soklet secara bertahap dengan pelarut campuran aceton dan metanol, kemudian petroleum ether, dan hexane masing masing selama 16 jam. Pelarut yang digunakan mempunyai kemurnian tinggi. Setelah diekstraksi PUF-disk kemudian dikeringkan pada suhu $50^{\circ} \mathrm{C}$ selama 4 jam dengan menggunakan dry vacum oven dengan purge gas N2. PUF-disk segera dimasukkan dalam kaleng stainless stell dan dirapatkan dengan isolasi teflon untuk mencegah masuknya udara kedalam kaleng selama proses transportasi ke lokasi sampling (7).

\section{Pemaparan Sampler}

Pengambilan sampel dilakukan dengan memaparkan PUF-disk yang telah dipreparasi dengan ditempatkan di tengah wadah berbentuk dua kubah stainless stell seperti piring terbang. Diantara dua kubah tersebut terdapat celah sebesar $2.5 \mathrm{~cm}$ yang berfungsi agar udara dapat masuk melewati celah tersebut dan mengalir melalui permukaan 
PUF-disk. Pengambilan sampel dilakukan secara pasif dengan asumsi sampel dalam bentuk gas akan lebih berinteraksi dengan PUF. Wadah kubah stainless stell tersebut berfungsi untuk melindungi PUF dari tetesan air hujan atau presipitasi, sinar matahari UV langsung, dan deposisi partikel ${ }^{(8)}$. Wadah juga berfungsi untuk mengurangi ketergantungan laju sampling terhadap kecepatan angin yang dihasilkan selama periode sampling. Untuk lokasi dengan kecepatan angin yang relatif rendah $(<4 \mathrm{~m} /$ detik) dan relatif seragam digunakan sampling rate rata rata $3 \mathrm{~m}^{3} /$ day dalam kisaran 2-4 $\mathrm{m}^{3}$ /day dari sampling rate hasil penelitian sebelumnya ${ }^{(1,2)}$. Laju sampling dipengaruhi oleh kondisi meteorologi seperti kecepatan angin ${ }^{(9)}$ oleh karena itu selain menggunakan laju sampling berdasarkan penelitian sebelumnya juga direkomendasikan untuk menggunakan laju sampling spesifik masing masing lokasi dengan menggunakan depuration compounds (DC) ${ }^{(8)}$.

Passive air sampler yang berisi PUF yang telah dipreparasi di Laboratorium Oil and POPs Research Group KORDI ditempatkan pada dua lokasi yang diasumsikan di daerah urban dan daerah rural yaitu di CawangJakarta sebagai daerah urban dan Citeko Puncak Bogor sebagai daerah rural. Daerah urban diasumsikan sebagai daerah dekat dengan transportasi dan aktifitas industri, sedangkan daerah rural diasumsikan masih bersih dan jauh dari aktifitas manusia dan kendaraan. Paparan PUF di udara ambien dilakukan dalam kurun waktu 63 hari yaitu di Jakarta dilakukan mulai tanggal 22 agustus - 24 Oktober 2011 sedangkan di Citeko Bogor mulai tanggal 25 Agustus- 27 Oktober 2011. Untuk menjaga keamanan dan memudahkan pengawasan selama paparan
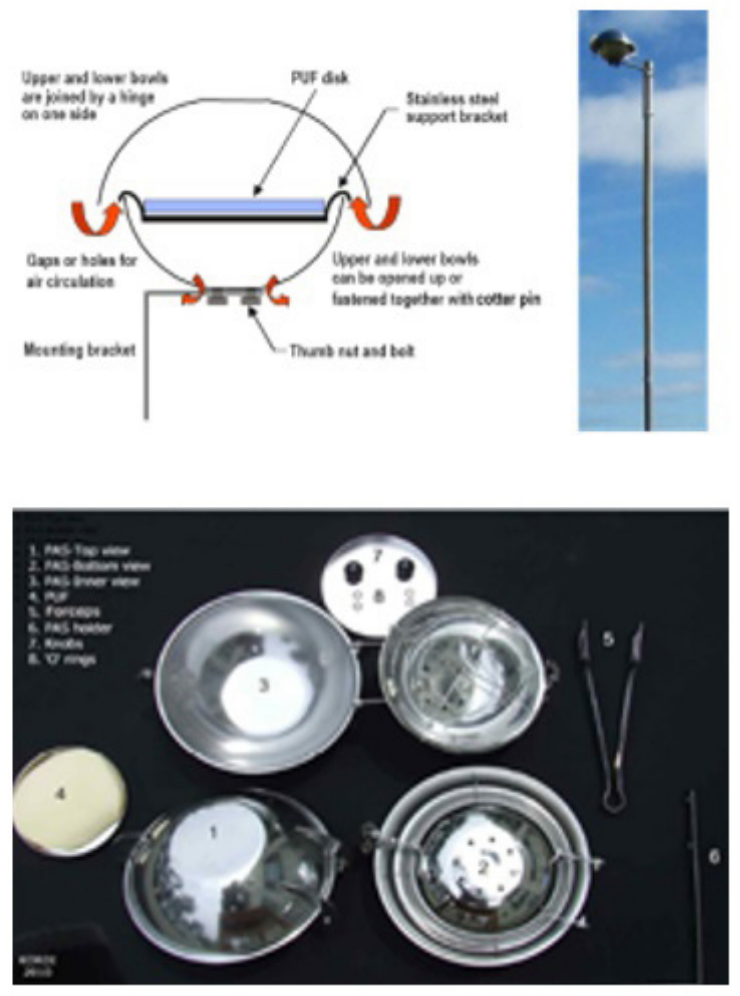

Sumber : SOP PAS Assembly and Development, KORDI Korea ${ }^{(10)}$

Gambar 1. PUF dalm PAS untuk pengambilan sampel POPs di diudara ambien. 
PUF berlangsung maka PAS ditempatkan diatap gedung yang berlokasi di Kebon Nanas Cawang Jakarta pada koordinat 6 14'0.76"S"; 106 52'39.18''E dan di Citeko Cisarua Puncak Bogor pada koordinat $6{ }^{\circ} 42$ '38.51's ; 106 57'0. 62'"E". Lokasi Citeko berada pada ketinggian $1144 \mathrm{~m}$ dpl. Pemanfatan lahan sebagian besar digunakan untuk villa dan pertanian hortikultur, sedangkan lokasi gedung di Cawang berada pada ketinggian $16 \mathrm{~m}$ dpl yang merupakan area dekat dengan jalan layang dan juga berbagai aktifitas yang lainnya.

\section{Ekstraksi dan Analisis}

PUF yang telah dipaparkan di udara dimasukan kembali dalam kaleng stainles stell yang ditutup dengan solasi teflon untuk ditransportasikan ke Laboratorium Oil and POPs Research Group KORDI untuk dilakukan ekstraksi dan analisis ${ }^{(10)}$. PUF-disk dipotong kecil kecil dengan gunting yang telah dicuci dengan DCM dan dimasukkan dalam timble filter yang berisi batu didih di dalam tabung soklet. POPs dalam PUF diekstrasi dengan pelarut hexane/ DCM $(1 ; 1)$ sebanyak $240 \mathrm{ml}$ dengan ekstraksi soklet selama 16 jam pada suhu $160^{\circ} \mathrm{C}$. Sebelum diekstrasi PUF ditambahkan standar surogate 20 ul 100 ppb (DBOFB, PCB103, PCB198). Setelah ekstraksi soklet selesai, batu didih diambil dan hasil ekstraksi dengan soklet di pekatkan dengan rotary evaporator pada suhu $30^{\circ} \mathrm{C}$ hingga volume mencapai 1-2 ml. Hasil pemekatan kemudian dilakukan pemurnian dengan menggunakan kolom silica/ alumia dengan komposisi kolom bagian atas $10 \mathrm{~g}$ sodium sulfat kemudian deactivated silica gel (5\% air berdasarkan berat:20g) ; diactivated alumina(1\% berdasarkan berat: $10 \mathrm{~g}$ ) dan lapisan paling bawahi $10 \mathrm{~g}$ sodium sulfat. POPs dielusi dengan 100 ml DCM. Hasil elusi dipekatkan dengan rotary evaporator pada suhu $25^{\circ} \mathrm{C}$ sampai volume menjadi 1-2 ml. Hasil pemekatan di pekatkan dengan gas N2 sampai volume $0.5 \mathrm{~mL}$. Hasil pemekatan dimurnikan lebih lanjut dengan menggunakan kolom HPLC (HPLC;250x22.5 mm i.d.size exclusion coloum packing with phenogel 100À). Hasil pemurnian dengan HPLC dipekatkan kembali dengan rotari evaporator pada suhu $25^{\circ} \mathrm{c}$ sampai 1-2 mL. Hasil pemekatan ditambahkan $15 \mathrm{ml}$ hexane untuk pergantian pelarut dan dipekatkan kembali sampai volume 1-2 mL. Hasil pemekatan rotari evaporator dipekatkan sampai volume kurang dari $0.5 \mathrm{ml}$ dengan nitrogen dan ditambahkan internal standar tetrachloro-m-xylene (TCMX), kemudian ditera sampai tepat $0.5 \mathrm{~mL}$ untuk dilakukan analisis. Analisis dengan menggunakan GCMS dengan kondisi GC; Colom DB-5MS (30mx0.25mmx0.25 um film), temperatur program initial $100^{\circ} \mathrm{C}\left(5^{\circ} \mathrm{C} / \mathrm{min}, 1 \mathrm{~min}\right)$, $140^{\circ} \mathrm{C}\left(1.5^{\circ} \mathrm{C} / \mathrm{min}, 1 \mathrm{~min}\right) ; 250^{\circ} \mathrm{C}\left(10^{\circ} \mathrm{C} / \mathrm{min}\right.$, $1 \mathrm{~min}$ ) final $300^{\circ} \mathrm{C}(5 \mathrm{~min})$. Gas pembawa $\mathrm{He}$ $1.2 \mathrm{ml} / \mathrm{min}$, injection mode splitless, volume injeksi 2 ul.

\section{HASIL DAN PEMBAHASAN}

Kelompok senyawa POPs telah dilarang penggunaannya baik di luar negeri maupun di Indonesia. Senyawa POPs yang digunakan untuk pertanian seperti DDT sudah jauh lebih lama dilarang penggunannya dibandingkan untuk penggunaan lainnya. Meskipun senyawa POPs telah dilarang penggunaannya namun karena sifatnya yang persiten dan dapat ditransportasikan secara global maka 


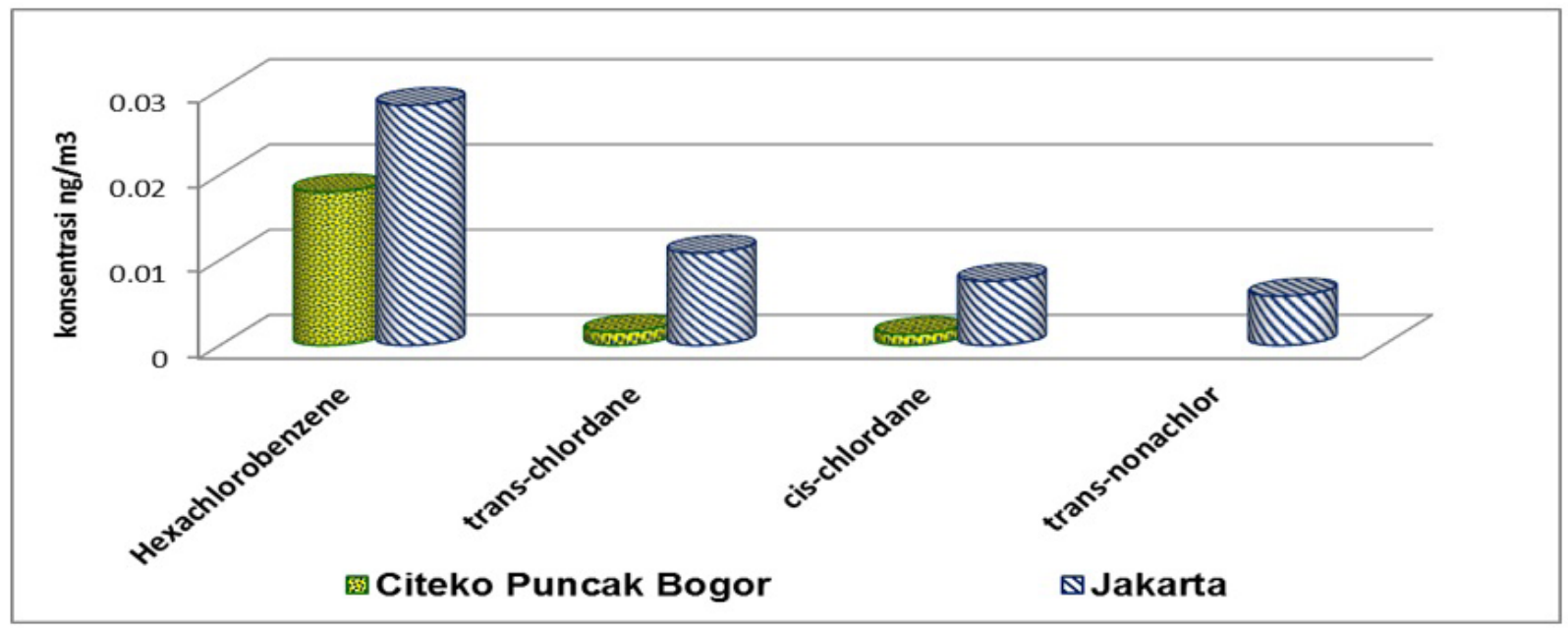

Gambar 2. Konsentrasi HCB, chlordane dan nonachlor di udara ambien.

senyawa POPs masih dapat dideteksi di lingkungan termasuk di udara ambien. Hal tersebut dibuktikan dengan hasil pengukuran POPs dengan menggunakan PAS yang menunjukkan keberadaan senyawa POPs di udara. Identifikasi senyawa POPs di udara ambien tersebut menunjukkan bahwa beberapa senyawa POPs masih terdeteksi di lokasi daerah rural Citeko Puncak Bogor dan di daerah urban Cawang Jakarta. Senyawa POPs yang terdeteksi di udara ambien adalah hexachlorobenzene (HCB), trans-chlordane, cis-chlordane, trans-nonachlor, PCBs, DDT dan turunannya yaitu pp'-DDT, op'-DDT, pp'-DDD, pp'-DDE. POPs yang tidak terdeteksi adalah heptachlor, endosulfan I, $\alpha-\mathrm{HCH} \gamma-\mathrm{HCH}$ (lindane), $\beta-\mathrm{HCH}, \delta-\mathrm{HCH}$, oxychlordane, cis-nonachlor, aldrin, endrin, dieldrin. Pengambilan sampel POPs di udara Citeko dan Jakarta secara pasif selama 63 hari menunjukkan keberadaan beberapa senyawa POPs pada kisaran konsentrasi 0.001-0.167ng/ $\mathrm{m}^{3}$. Gambar 2 menunjukkan konsentrasi $\mathrm{HCB}$, trans-chlordane, cis-chlordane dan trans-nonachlor yang terdeteksi di udara ambien Citeko Bogor dan Cawang Jakarta.
HCB terdeteksi di derah urban Jakarta dengan konsentrasi $0.028 \mathrm{ng} / \mathrm{m}^{3}$ sedangkan di daerah rural Citeko Puncak Bogor terdeteksi dengan konsentrasi $0.018 \mathrm{ng} / \mathrm{m}^{3}$. Konsentrasi $\mathrm{HCB}$ tersebut masih berada dalam kisaran konsentrasi HCB yang dideteksi Asia (China, Philipina, Thailand, Vietnam, Malaysia, Srilanka, India) dengan nilai antara $0.010-0.520 \mathrm{ng} / \mathrm{m}^{3}$ dan masih berada jauh dibawah nilai maksimum yang ditemukan ${ }^{(6)}$. Penggunaan HCB untuk fungisida telah dilarang demikian juga untuk penggunaan lain seperti produksi karet, aluminium, pencelupan serta pengawetan kayu. Saat ini HCB dapat terlepas ke lingkungan dari kegiatan industri atau cerobong emisi sebagai produk samping selama proses industri bahan kimia (pelarut) dan juga sebagai pengotor dalam beberapa produk pestisida. Sejumlah HCB juga terbentuk selama proses pembakaran sampah perkotaan, pembakaran semen, batubara, limbah lumpur, biomasa, limbah medis, pembakaran semen ${ }^{(11)}$. Kondisi tersebut sejalan dengan hasil pengukuran yang menunjukkan konsentrasi HCB di perkotaan lebih tinggi dibandingkan dengan 
di pedesaan. HCB bersifat persisten dan jika terlepas ke udara HCB akan ada dalam bentuk fase uap dan dengradasinya berlangsung sangat lama dan mudah ditransportasikan jarak jauh di udara ${ }^{(11)}$. Karena sifat HCB yang bersisten dan mudah ditransportasikan secara global maka HCB bisa berada dimana saja termasuk di daerah yang terisolir. Rasio HCB di daerah urban Jakarta dan di daerah rural Citeko-Bogor yang relatif kecil sebesar 1.5 jika dibandingkan dengan rasio senyawa POP lainya dan sifat persistennya di udara memberikan indikasi bahwa HCB di udara ambien mayoritas berasal dari global transportasi. Konsentrasi HCB yang terdeteksi lebih tinggi di Jakarta dimungkinkan adanya tambahan sumber pencemar lokal yang berasal dari produk samping dari proses industri yang ada di perkotaan.

Total chlordane yang terdeteksi di rural Citeko Bogor sebesar $0.003 \mathrm{ng} / \mathrm{m}^{3}$ sedangkan di urban Jakarta $0.024 \mathrm{ng} / \mathrm{m}^{3}$. Konsentrasi total chlordane tersebut juga berada dalam kisaran konsentrasi total chlordane yang terdeteksi di Asia dengan kisaran 0.001 $0.273 \mathrm{ng} / \mathrm{m}^{3}{ }^{(6)}$. Secara teknis chlordane bukan komponen kimia tunggal tetapi dari berbagai bahan kimia terkait, dengan komponen utama seperti trans chlordane, cis chlordane, beta chordane heptachlor dan trans nonachlor ${ }^{(12)}$. Chlordane yang terdeteksi di udara ambien Cawang Jakarta meliputi senyawa trans-chlordane, cis-chlordane dan trans-nonachlor dengan konsentrasi secara berurutan $0.011 \mathrm{ng} / \mathrm{m}^{3}, 0.008 \mathrm{mg} / \mathrm{m}^{3}$ dan $0.006 \mathrm{mg} / \mathrm{m}^{3}$ sedangkan di daerah rural Citeko Puncak Bogor trans-nonacklor tidak ditemukan hanya senyawa trans chlordane dan cis chlordane yang terdeteksi dengan konsentrasi secara berurutan $0.002 \mathrm{mg} / \mathrm{m}^{3}$ dan $0.001 \mathrm{mg} /{ }^{3}$ (Gambar 2). Konsentrasi trans dan cis chlordane tersebut juga masih jauh berada dibawah konsentrasi maksimum trans dan cis chlordane di Asia yang berada pada kisaran nilai 0.001-0.134 ng/m ${ }^{3}$ (6). Chlordane merupakan bahan kimia buatan pabrik yang pertama kali digunakan di Amerika serikat pada tahun 1948 sebagai pestisida untuk pertanian dan kebun dan tahun 1978 dihentikan penggunaan untuk persitisa pertanian karena sifatnya yang persisten di lingkungan dan berbahaya tehadap mahkluk hidup serta menimbulkan resiko kanker. Chlordan kemudian digunakan untuk pengendalian rayap di gedung gedung atau bangunan perumahan dari tahun 1983-1988. Tahun 1988, EPA menghapus penggunaan untuk pengendalian rayap. Keberadaan chlordane di atmosfer cepat terpecah oleh cahaya dan bahan kimia lain di atmosfer, dan dapat bertahan lama serta dapat ditransportasikan secara global dengan jarak yang jauh. Hal ini digambarkan dengan terdeteksinya senyawa trans chlordane cis chlordane dan trans nonachlor sebagai beberapa componen chlordane yang masih terdeteksi di udara. Keberadaan chlordane di daerah perkotaan juga lebih tinggi dibandingkan di daerah urban dimungkinkan dari sisa penggunaan chlordane untuk pengendalian rayap di perkotaan sedangkan pengunaan chlordane untuk pertanian sudah dilarang jauh lebih lama dibandingkan untuk termisida ${ }^{(12)}$.

Komponen yang paling melimpah dalam tehnikal chlordane adalah trans chlordane dan cis chlordane (TC:CC) dengan rasio $1.2^{(13)}$. Rasio TC:CC menunjukkan umur chlordane, dimana rasi $\mathrm{TC}: \mathrm{CC}>1.2$ menunjukkan 
masukan baru chlordane ke udara. Di daerah rural Citeko Bogor rasio TT:CC sebesar 1.2 sedangkan di daerah urban rasio $\mathrm{TC}: \mathrm{CC}$ adalah 1.4 telah lebih besar dari 1.2 sehingga di urban dimungkinkan adanya masukan baru dari chlordane.

Total DDTs terdeteksi di rural Citeko Bogor dengan konsentrasi $0.024 \mathrm{ng} / \mathrm{m}^{3}$ dan di urban dengan konsentrasi $0.370 \mathrm{ng} / \mathrm{m}^{3}$. Konsentrasi total DDTs tersebut berada dibawah nilai maksimum DDTs yang terdeteksi di Asia dengan kisaran 0.028-1.586 ng/m ${ }^{3}{ }^{(6)}$. Di lingkungan, senyawa induk DDT akan terdegradasi menjadi DDD dan DDE. Hasil pengukuran dengan pasif air sampler di udara ambien daerah urban Jakarta menunjukkan bahwa senyawa induk pp-DDT masih terdeteksi dengan konsentrasi $0.096 \mathrm{ng} / \mathrm{m}^{3}$ dan tiga senyawa turunan DDT yaitu op-DDT, pp-DDD dan pp DDE terdeteksi secara berutan sebesar $0.036 \mathrm{ng} / \mathrm{m}^{3}, 0.167 \mathrm{ng} / \mathrm{m}^{3}$ dan 0.072 $\mathrm{ng} / \mathrm{m}^{3}$. Di daerah pedesaan hanya terdeteksi senyawa induk pp-DDT sebesar $0.016 \mathrm{ng} /$ m3 dan satu turunannya yaitu pp-DDE sebesar $0.008 \mathrm{ng} / \mathrm{m}^{3}$. Di daerah urban Jakarta senyawa induk pp-DDT terdeteksi lebih rendah dibandingkan dengan turunannya DDE dan DDD namun untuk daerah rural Citeko Bogor, senyawa induk DDT terdeteksi lebih tinggi dibandingkan turunannya meskipun keberadan pp-DDT di rural lebih rendah dibandingkan di Jakarta. Rasio pp-DDT dan pp DDE dapat menggambarkan umur DDT tersebut apakah merupakan penggunaan baru atau sisa penggunaan masa lalu. Rasio pp-DDT/pp-DDE $>1$ menunjukkan adanya masukan baru DDT ke lingkungan sedangkan rasio DDT/DDE $<1$ menunjukkan keberadaan DDT tersebut merupakan sisa penggunakan masa lalu. Rasio DDT/DDE di urban Jakarta terlihat $<1$ sedangkan di rural Bogor rasio DDT/DDE >1 menunjukkan pp-DDT terdeteksi lebih tinggi dibandingkan dengan turunannya. Keberadaan senyawa induk ppDDT yang lebih tinggi dibandingkan dengan turunannya memberikan indikasi bahwa dimungkinkan di lokasi pedesaan senyawa DDT masing digunakan secara ilegah untuk pemberantasan hama tanaman pertanian. Hal tersebut juga sejalan dengan hasil pemantauan

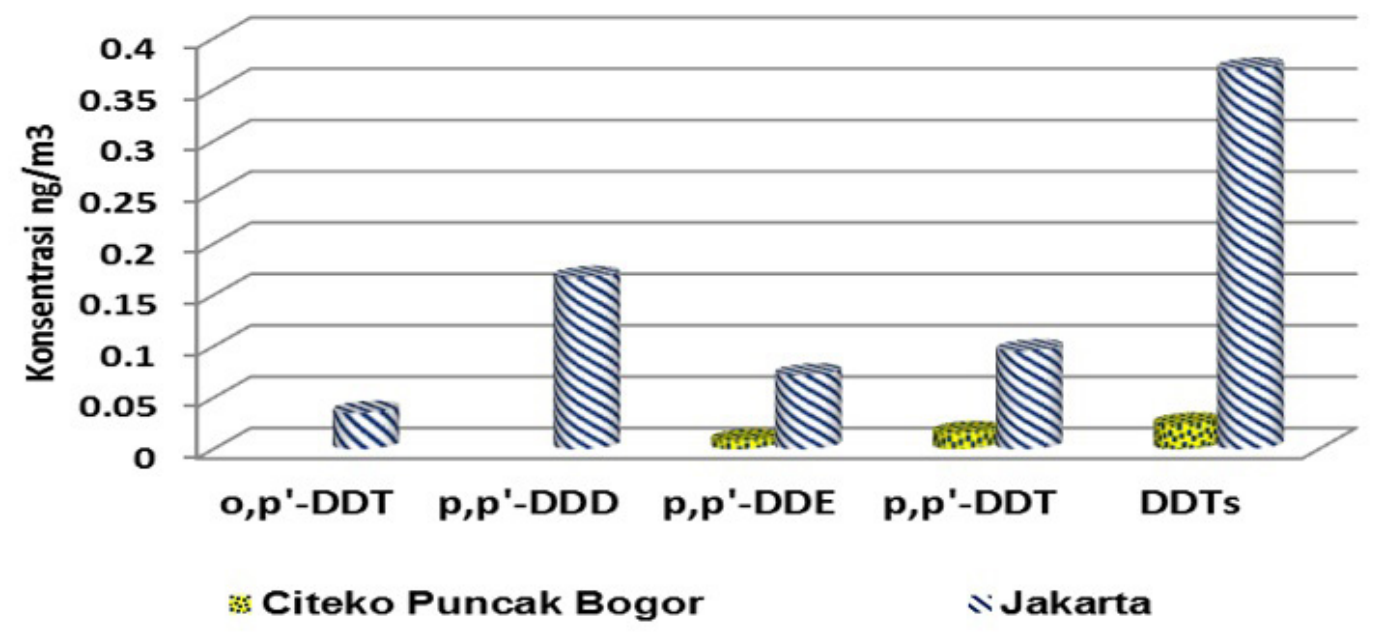

Gambar 3. DDT dan turunannya di udara ambien. 
yang dilakukan oleh Pusarpedal bahwa di tanah pertanian pp DDT terdeteksi lebih tinggi dibandingkan dengan turunannya. Secara umum konsentrasi total DDT di titik pantau Cawang Jakarta lebih tinggi daripada di Citeko Cisarua Puncak Bogor (Gambar 3).

PCBs juga terdeteksi di udara ambien dengan jenis dan konsentrasi yang berbeda antara daerah rural dan urban. Konsentrasi total PCBs di daerah urban Cawang Jakarta jauh lebih tinggi dibandingkan dengan di daerah rural Citeko Bogor, demikian juga dengan jenis PCB di Jakarta lebih banyak terdeteksi (Gambar 4). PCBs di udara ambien terdeteksi pada kisaran konsentrasi 0.001 $0.016 \mathrm{ng} / \mathrm{m}^{3}$. PCBs di Citeko Bogor hanya terdeteksi untuk PCB8, PCB 18 dan PCB

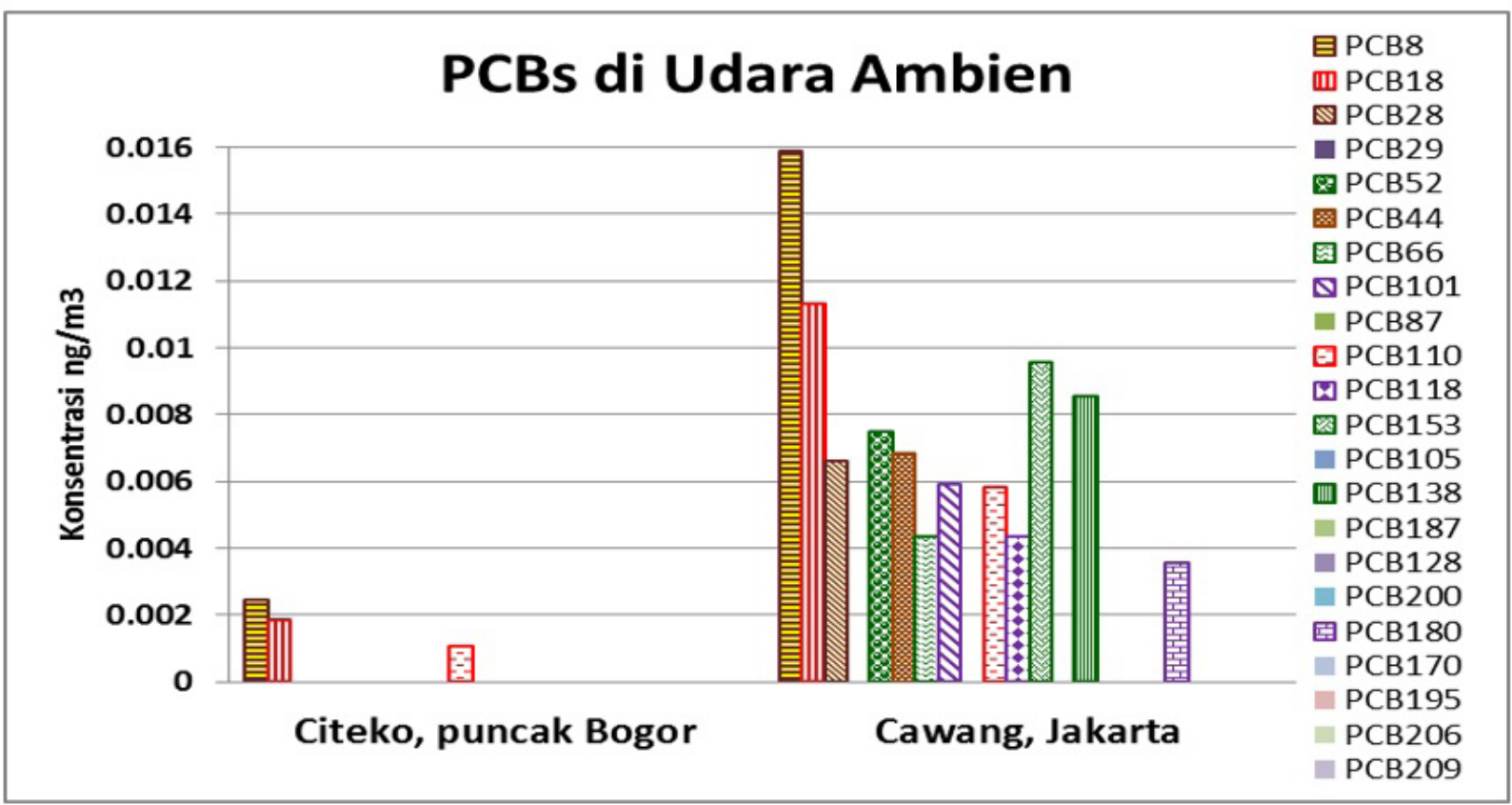

Gambar 4. Konsentrasi PCBs di rural dan urban area.

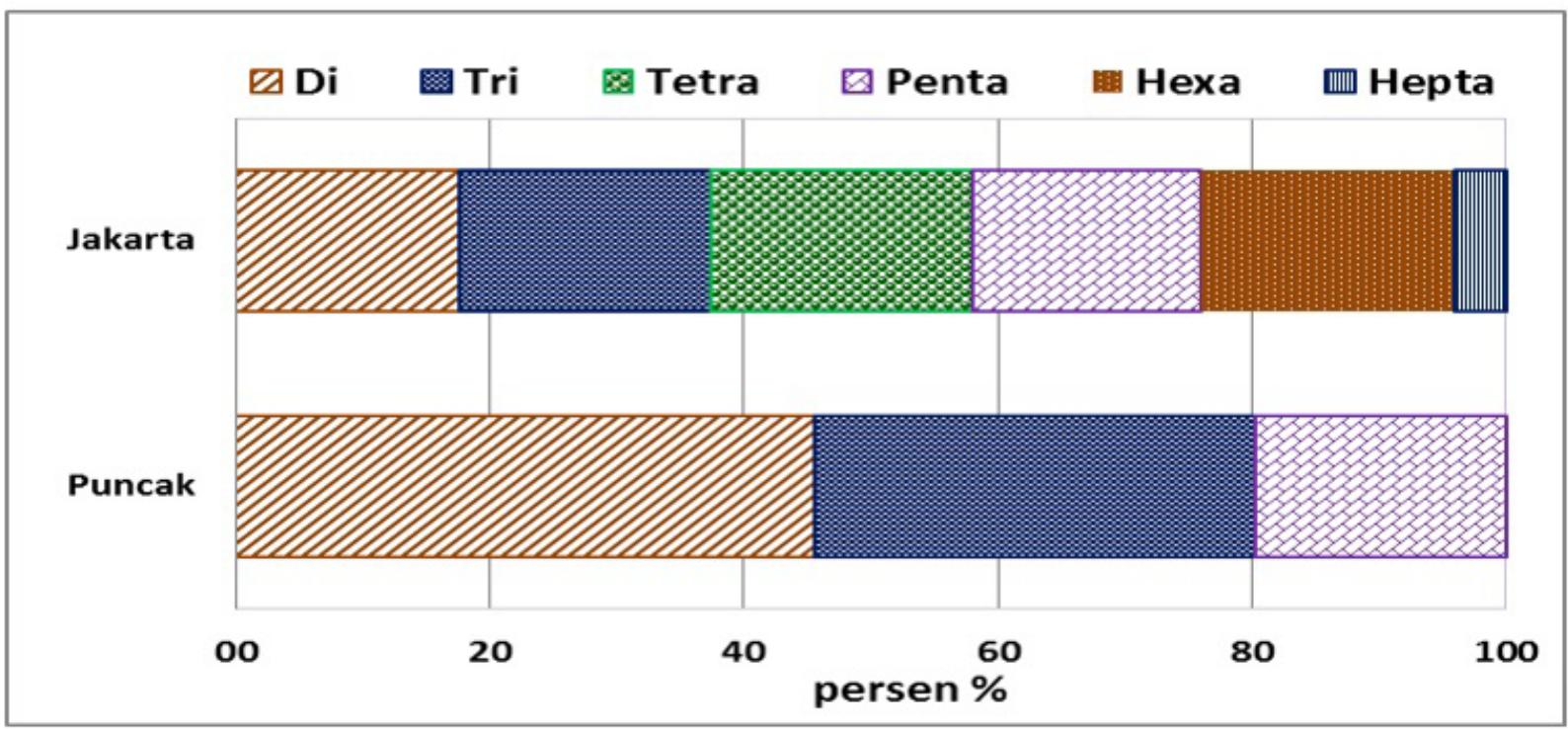

Gambar 5. Profil PCB homologs. 
110 yang merupakan homolog dari Di-PCBs, Tri-PCBs dan Penta- PCBs dengan konsentrasi secara berurutan adalah $0.003 \mathrm{ng} / \mathrm{m} 3,0.002$ $\mathrm{ng} / \mathrm{m}^{3}$ dan $0.001 \mathrm{ng} / \mathrm{m}^{3}$. Konsentrasi $\sum_{12} \mathrm{PCBs}$ di udara Cawang Jakarta yang terdiri dari PCB8, PCB18, PCB28, PCB52, PCB44, PCB66, PCB101, PCB110, PCB118, PCB 153, PCB 138, PCB 180 berada pada kisaran $0.003-0.016 \mathrm{ng} / \mathrm{m}^{3}$. Total PCBs sebesar 0.09 $\mathrm{ng} / \mathrm{m}^{3}$. Konsentrasi tertinggi terdeteksi untuk PCB8 yang merupakan Di-PCBs.

Gambar 5. menunjukkan PCB homolog yang diambil dari lokasi di Jakarta sebagai daerah urban dan PCB homolog di daerah rural Citeko Puncak Bogor. PCB homolog di Jakarta lebih bervariasi dibandingkan dengan PCB homolog di Citeko Bogor. Berdasarkan homolog PCBs maka setiap PCB homolog mempunyai sifat fisik dan kimia yang sangat bervariasi sehingga dapat menentukan keberadaan dilingkungan maupun transportasinya di atmosfer ${ }^{(13)}$. PCB kongener yang ringan akan mudah menguap dan ditransportasikan melalui atmosfer ke daerah remote lainya, sedangkan kongener yang berat akan cenderung mengendap. Profil PCB yang diambil di wilayah Puncak hanya terdiri dari tiga PCB homolog yaitu Di-PCBs, Tri-PCBs dan penta-PCBs, dengan dominasi oleh PCB homolog yang ringan yaitu Di-PCBs sebesar $45.6 \%$ sedangkan untuk Tri-PCBs dan penta-PCBs secara berutan berurutan sebesar 34.7 dan 19.7 \%. Kongener PCB yang lebih berat yaitu Hexa sampai decaPCB tidak ditemukan di daerah rural yang berada di Citeko-Bogor pada ketingginan $1144 \mathrm{~m}$ dpl. Hal tersebut memberikan indikasi bahwa PCBs yang terdapat di daerah Puncak dimungkinkan bukan berasal dari sumber pencemar lokal namun dimungkinkan ditransportasikan dari daerah urban sehingga hanya PCBs yang ringan yang ditemukan di daerah rural Citeko Bogor. PCBs yang terdeteksi di daerah perkotaan yaitu di Cawang Jakarta lebih bervariasi dari di-PCB sampai hepta-PCB terdeteksi di Jakarta. Octa dan deca-PCB tidak ditemukan di udaram ambien Jakarta. Sebaran homolog PCB di Jakarta tersebut relatif serupa kurang lebih $20 \%$ kecuali untuk Hepta PCB yang hanya $3 \%$. Keberadaan PCB yang lebih bervariasi di Jakarta sangat dimungkinkan karena beragam dan banyaknya aktivitas di Jakarta yang memungkinkan sebagai sumber lokal pelepasan PCBs ke udara ambien disamping adanya sumber pencemaran dari global transportasi.

Terdeteksinya beberapa senyawa POPs di udara ambien dan adanya potensi rasio yang mengindikasikan adanya masukan baru beberapa senyawa POPs ke lingkungan memberikan indikasi adanya kemungkinan penggunaan POPs secara ilegal. Keberadaan POPs dilingkungan perlu diidentifikasi lebih lanjut untuk mendukung upaya pengawasan dan pengendalian penggunaan POPs secara ilegal.

\section{SIMPULAN}

PAS sangat bermanfaat untuk pengambilan sampel POPs di udara ambien karena sederhana dan tidak membutuhkan tenaga listrik sehingga dapat ditempatkan di daerah urban, rural maupun daerah terisolir. POPS yang dilarang penggunaannya masih terdeteksi diudara ambien baik di urban Cawang-jakarta maupun di rural Citeko Puncak-Bogor. POPs didaerah urban Jakarta terdeteksi lebih tinggi dibandingkan dengan di daerah 
rural Citeko Puncak Bogor namun potensi terjadinya masukan baru senyawa POPs ke lingkungan bisa terjadi di daerah urban dan rural. HCB didaerah rural bukan berasal dari sumber pencemar lokal namun dari transportasi global. Rasio trans chlordane dan cis chlordane $(\mathrm{TC}: \mathrm{CC})>1.2$ di daerah urban menunjukkan masih terjadi masukan baru senyawa tersebut di udara ambien. DDT dan turunannya terdeteksi dengangan konsentrasi senyawa induk lebih tinggi dibandingkan dengan turunannya di daerah rural. PCBs di urban terdeteksi lebih tinggi dengan variasi yang lebih beragam dibandingkan di daerah rural.

\section{UCAPAN TERIMAKASIH}

Ucapan terimaksih disampaikan kepada Dr Won Joon Shim, Dr Sang Hee Hong dan semua personil Oil and POP Laboratory, Korean Ocean Research and Development Institute (KORDI) melalui program AMETEC-UNU di Geoje Korea Selatan yang telah menyediakan dana, sarana dan prasarana maupun transfer ilmu dan pengetahuan dalam kegiatan ini dan serta semua pihak yang telah membantu terselenggaranya kegiatan ini.

\section{DAFTAR PUSTAKA}

(1) Shoeib M and T harner 2002. Characterization and comparation of three passive Air sampler for persistent organicpollutants. Environmental Science technology 36 ( 94142-4151)

(2) Harner T., K Pozo, T Gouin, Am Macdonald, H Hung, J Cainey, A Peters. 2005. Global pilot study for persistent organic pollutants (POPs) using PUF disk passive air samplers. Environ. Poll. 144. 445-452
(3) Pozo K, harnerT, Wania F, Muir DCG, Jones KC barrie LA.2006 Toward a global network for persistent organic pollutants in air; result from the GAPsstudy. Environ Sci Technol 40(4867-4873)

(4) Harner T, M Shoeib, M diamond, G Stern, B rosenberg 2004. Using Passive Air Samplers to Asses Urbanrural Trends for Persistent Organic Pollutants.PCB adn organochlorine Pesticides. Environmental Science technology 38 (4474-4486)

(5) Kennedy K, D W hawker, ME bartkow, S Carter, Y ishikawa, JF Mueller, 2010. Theferential ambient and deployment chamber temperatures on PRC derived sampling rates with polyurethane foam(PUF) passive air samplerEnvironmental Pollution 158 (142-147)

(6) EPA, 2015. Persistent Organic Pollutants: A Global Issue, A Global Response diakses 23 januari2016 (http://www.epa.gov/internationalcooperation/persistent organicpollutants-global-issue-globalresponse)

(7) AMETEC-UNU training workhop. 2011. Passive air sampling : Long range transport of Persistent Organic Pollutants (POPs), KORDI Geoje

(8) Pozo K., Tom Harner, M Shoeib, Roberto U, Ricardo B, Oscar P., and Silvano F.2004. Passive-Sampler derived Air Concentration of Persistent Organic Pollutants on a North-South Transect in Chile. Environ. Sci. Technol. 38,6529-6537.

(9) Tuduri,L, T Harner, Hung 2006. Polyurethane fpam(PUF) disk passive air samplers:Wind effect ons ampling rate. Environ.Pollution 144,377-383 
(10) KORDI, 2011. Passive Air sampler assembly and Development, Standard Operation Procedure. Geoje Korea.

(11)ASTDR. Toxicological Profile for Hexachlorobenzene. http:// www.atsdr.cdc. gov/ toxprofiles/ tp.asp? $\mathrm{id}=627 \& \mathrm{tid}=115$ diakses 24 januari 2016)

(12)ASTDR. Public Health Statement Chlordane (http://www.atsdr.cdc.gov/ ToxProfiles/tp31-c1-b.pdf, diakses 26 januari 2016)
(13) Jantunen, L.M.M., Bidleman, T.F., Harner, T. and Parkhurst, W.J. (2000). Toxaphene, Chlordane, Andother Organochlorine Pesticides in Alabama Air. Environ. Sci. Technol . 34: 5097-5105.

(14) Li YM, Geng D W, Hu Y B, et al. 2012. Levels and distribution of polychlorinated biphenils in the atmosphereclose to chinese great Wall Station, Antartica: result from XADresin passive airs ampling. Chin Sci Bull 57: 14991503 